Industrial Health, 1978, 16, 119.

\title{
SIMULTANEOUS EFFECTS OF DIETARY MOLYBDENUM AND COPPER ON THE ACCUMULATION OF COPPER IN THE LIVER AND KIDNEY OF COPPER POISONED RATS. A HISTOCHEMICAL STUDY
}

\author{
S. V.S. RANA and AJAY KUMAR \\ School of Environmental Contamination \& Toxicology, Department of \\ Zoology, D.A.V. College, Muzaffarnagar-251001, India
}

(Received November 28, 1978)

\begin{abstract}
The present investigation reports on the accumulation and damage caused by copper in the liver and kidney of albino rats. Simultaneous treatment with copper and molybdenum shows that no traces of copper are retained in these tissues. Thus these observations lead to the conclusion that copper is ineffective in the presence of molybdenum exhibiting physiological antagonism. Several hypothesises have been considered for their antagonistic behaviour. Present authors suggest that molybdenum may act on copper as a chelating agent binding with it and forming either cupric molybdate or copper thiomolybdate which is ultimately excreted. Intake of molybdenum with the diet has also been suggested for the occupational victims of copper.
\end{abstract}

Though copper is present in most vertebrate tissues as an essential component of a metalloenzyme systems, like other heavy metals it can be cumulative in the animal body causing appreciable damage. The first report of chronic copper poisoning appears to be that of Mallory (1925). ${ }^{1)} \quad$ Further reports appeared in the 1930's. These and other reports have been reviewed by Broughton and Hardy (1934), ${ }^{2)}$ Eden (1940) ${ }^{3)}$ and Todd $(1962,1969) .4,5) \quad$ It is important to appreciate that molybdenum can either increase or decrease the copper status of an animal depending on their intakes relative to that of copper. Mills $(1961)^{6}$ contended that molybdate and sulfate restrict copper utilization in sheep by precipitating insoluble cupric sulfide. Other reports favouring physiological antagonism are those of Dick $(1954,1956){ }^{7,8)}$ However, Hogan et al. (1966) ${ }^{9)}$ failed to reduce copper contents of liver and brain in lambs after dozing their mothers with molybdate. To confirm further their relationship, attempt has been made to note the protective effects of molybdenum on the pathological accumulation of copper in the liver and kidney of adult rats (Rattus rattus albino) employing histochemical parameters. Histological improvement if any, has heen attributed to the antagonistic behaviour of molybdenum. 


\section{S.V.S. RANA AND A. KUMAR}

\section{Materials And Methods}

Adult albino rats of both sexes weighing 90 to $110 \mathrm{~g}$ were selected from the lab. stock. They were at random divided into three groups each containing ten rats. Each rat was housed separately in a suitable cage, fed on laboratory diet (Hindustan Lever Ltd. Bombay) and tap water ad libitum. Members of the group A were fed in addition to the lab. diet on $100 \mathrm{mg} / \mathrm{kg}$ body weight copper sulfate (BDH mol. weight 249.69) for 20 days by intubation. Rats of group B were fed in addition to copper and lab. diet on $1.0 \mathrm{gm} / \mathrm{kg}$ body weight ammonium molybdate (BDH mol. weight 195.966) for the same duration. Rats of group $\mathrm{C}$ enjoyed laboratory diet alone and tap water.

On 22nd day, all the rats were killed by etherization. Few pieces of liver and kidney were processed for routine histopathological examination and others for the histochemical detection of copper (Okamoto and Utamura, 1938). ${ }^{10}$

\section{RESUlts}

Histopathological changes as manifestations of chronic copper poisoning thus recorded in the liver and kidney are as follows:

In the liver from the rats of group $\mathrm{A}$ (fed on $\mathrm{Cu}$ ), first clear sign was the centrolobular necrosis. Parenchymal cells of the central region exhibited degeneration (Fig. 1). Perilobular sclerosis with nuclear edema was also observed (Fig. 2). After simultaneous feeding on copper and molybdenum, binucleated cells were observed at the perilobular region. Though nuclear swelling was observed but the whole tissue showed no degeneration and necrosis (Fig. 3). Liver of the control rats exhibited normal histological features (Fig. 4).

Kidney of copper treated rats showed engorgement of uriniferous tubules. Necrosis of the tubule was also noted. Glomeruli remained unaffected (Fig. 5). Clumping and nuclear proliferation was also observed in the medullary region (Fig. 6). Histopathological changes in the kidney after copper and molybdenum treatment were found less severe in comparison to group A. Necrosis of the tubule was absent, however, glomerulonephritis was observed (Fig. 7). Medullary region exhibited nuclear clumping (Fig. 8).

The above observations prove that molybdenum exerts some protective effects against copper poisoning or so called Wilson's disease in the liver and kidney of rats.

To know whether molybdenum is able to check the accumulation of copper in liver and kidney, histochemical test for copper was also performed. In the liver of rats fed on copper (Group A), heavy deposition was observed in the centrolobular parenchyma. Slight deposition occurred at the perilobular zone also (Fig. 9). After simultaneous feeding on copper and molybdenum with the diet, no retention of copper occurred in the liver (Fig. 10). This observation confirms the physiological antagonism between Mo and 


\section{EFFECT OF DIETARY Mo AND Cu ON COPPER ACCUMULATION}

$\mathrm{Cu}$ in vivo also. Kidney of copper treated rats also exhibited retention of copper in the epithelium of distal tubules (Fig. 11). Interstitium and medullary cells also retained some amount of copper (Fig. 12). In $\mathrm{Cu}+\mathrm{Mo}$ exposed rats copper was wanting from all regions of kidney. (Fig. 13, 14). This observation from kidney again favours the above conclusion. It can be safely said that in the presence of molybdenum in the diet at a higher ratio copper is not cumulative.

\section{Discussion}

No retention of copper in the liver and kidney after simultaneous treatment with Mo and $\mathrm{Cu}$ clearly indicates the nature of physiological antagonism between molybdenum and copper. The mechanisms of the complex effect of Mo on $\mathrm{Cu}$ has been extensively studied during the last twenty years. Mills $\left.(1961)^{6}\right)$ contended that molybdate and sulfate restrict copper utilization in sheep by depressing copper solubility in the digestive tract through the precipitation of insoluble cupric sulfide. Suttle (1974) ${ }^{11}$ has shown that Mo interacts with organic sulfur (cysteine and methionine) as well as inorganic sulphur, limiting the utilization of copper administered with diet. It was stated further that the interaction between copper, molybdenum and sulphur takes place predominantly in the gut and may invade the formation of an unavailable compound containing copper and molybdenum similar to that described by Dowdy and Matrone (1968). ${ }^{12}$ A hypothesis recently put-forward by Huisingh et al. $(1973)^{13)}$ proposes that copper becomes unavailabe through interaction with molybdate to form a biologically unavailable $\mathrm{Cu}-\mathrm{Mo}$ complex called cupric molybdate which appears to be absorbed, transported and excreted as a unit and makes both $\mathrm{Cu}$ and Mo less available. Present authors suggest that cupric molybdate or copper thiomolybdate thus formed is not absolutely beneficial to the tissue, as partial damage to liver and kidney has been noted in the rats of group B. However, present author suggest that Mo may act on copper as a chelating agent which binds with $\mathrm{Cu}$ forming any of the two compounds that are ultimately excreted. No reaction for $\mathrm{Cu}$ in liver and kidney after $\mathrm{Cu}+$ Mo treatment proves its mobilization and excretion from the tissues.

On the basis of above data, it can safely be concluded that Mo may be a perfect remedy against copper poisoning but certain points need further discussion. Firstly, particular level of $\mathrm{Cu}$ may be made unabsorbable by a certain ratio of dietary Mo. Further it should no more cause copper deficiency. Recent evidences obtained by Suttle (1973) ${ }^{14}$ indicate that $\mathrm{Mo}$ can interfere with $\mathrm{Cu}$ metabolism at dietary levels below $5 \mathrm{ppm}$. His results suggest that difference of $1 \mathrm{ppm}$ in dietary molybdenum are of significance to ruminants in respect to copper utilization. The present $\mathrm{Mo}: \mathrm{Cu}(10: 1)$ ratio has been found quite effective. The suitable ratio is important since Mo may exert independent toxic effects. After the removal of $\mathrm{Cu}$, repair of the damaged tissue remains questionable since present observations show alterations in the liver and kidney of $\mathrm{Mo}+\mathrm{Cu}$ treated rats. An over all conclusion that Mo might serve as an essential tool in the 


\section{S.V.S. RANA AND A. KUMAR}

occupational hazards of copper can be drawn. However, suitable therapy might be evolved for improvement in the tissue structure and function. To note the extent of functional injury or recovery enzyme histochemical studies are in progress in this laboratory.

The authors gratefully acknowledge the State Council of Science and Technology for providing the financial assistance.

\section{REFERENCES}

1) Mallory, F.B. (1925). Am. J. Pathol., 1, 119.

2) Broughton, I.B. and Hardy, W.T. (1934). Texas Agric. Res. Stn. Bull., No. 499.

3) Eden, A. (1940). J. Comp. Pathol., 53, 90.

4) Todd, J.R. (1962). Vet. Bull., 32, 573.

5) Todd, J.R. (1969). Proc. Nutr. Sci., 28, 189.

6) Mills, C.F. (1961). Rowell Res. Inst. Collect. Papers, 17, 71.

7) Dick, A.T. (1954). Aust. J. Agric. Res., 5, 511.

8) Dick, A.T. (1956). Soil Sci., 81, 229.

9) Hogan, K.G., Ris, D.R. and Hutchinson, A.J. (1966). New Zealand J. Agric. Res., 9, 691.

10) Okamoto, K. and Utamura, M. (1938). Trans. Soc. Pathol. Japan, 22, 361.

11) Suttle, N.F. (1974). Trace Element Metabolism in Animals. 2, (Edited by Hoekstra, W.G., Suttle, J.W., Ganther, H.E. and Mertz, W.) University Park Press, Baltimore.

12) Dowdy, R.P. and Matrone, G. (1968). J. Nutr,. 95, 191.

13) Huisingh, J., Gomey, G.G. and Matrone, G. (1973). Fed. Proc., 32, 1921.

14) Suttle, N.F. (1973). Trace Substances in Environmental Health VII (Edited by Hemphill, D.D.) University of Missouri, Columbia. 
EFFECT OF DIETARY Mo AND Cu ON COPPER ACCUMULATION
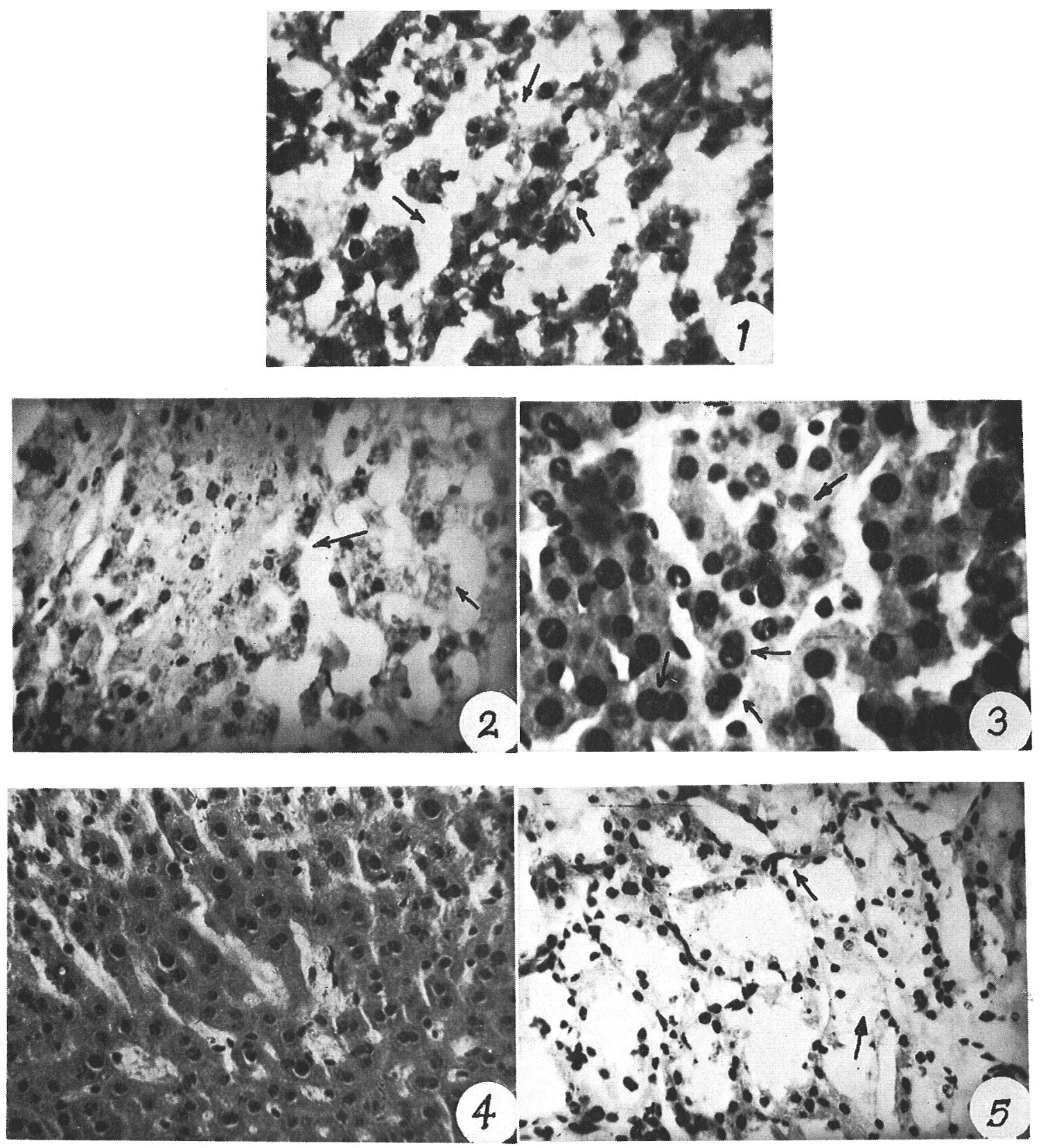

Fig. 1. T.S. of the liver from a copper fed rat shows centrolobular necrosis and parenchymal degeneration. $\times 320$.

Fig. 2. Copper treated rat liver also developed perilobular sclerosis with nuclear changes. $\times 320$.

Fig. 3. Binucleated cells are observed in the liver of rats fed on copper and molybdenum. $\times 480$.

Fig. 4. Intact parenchyma is exhibited by a T.S. of liver from the control rats. $\times 320$.

Fig. 5. A section of kidney from copper treated rats shows tubular necrosis. $\times 240$. 

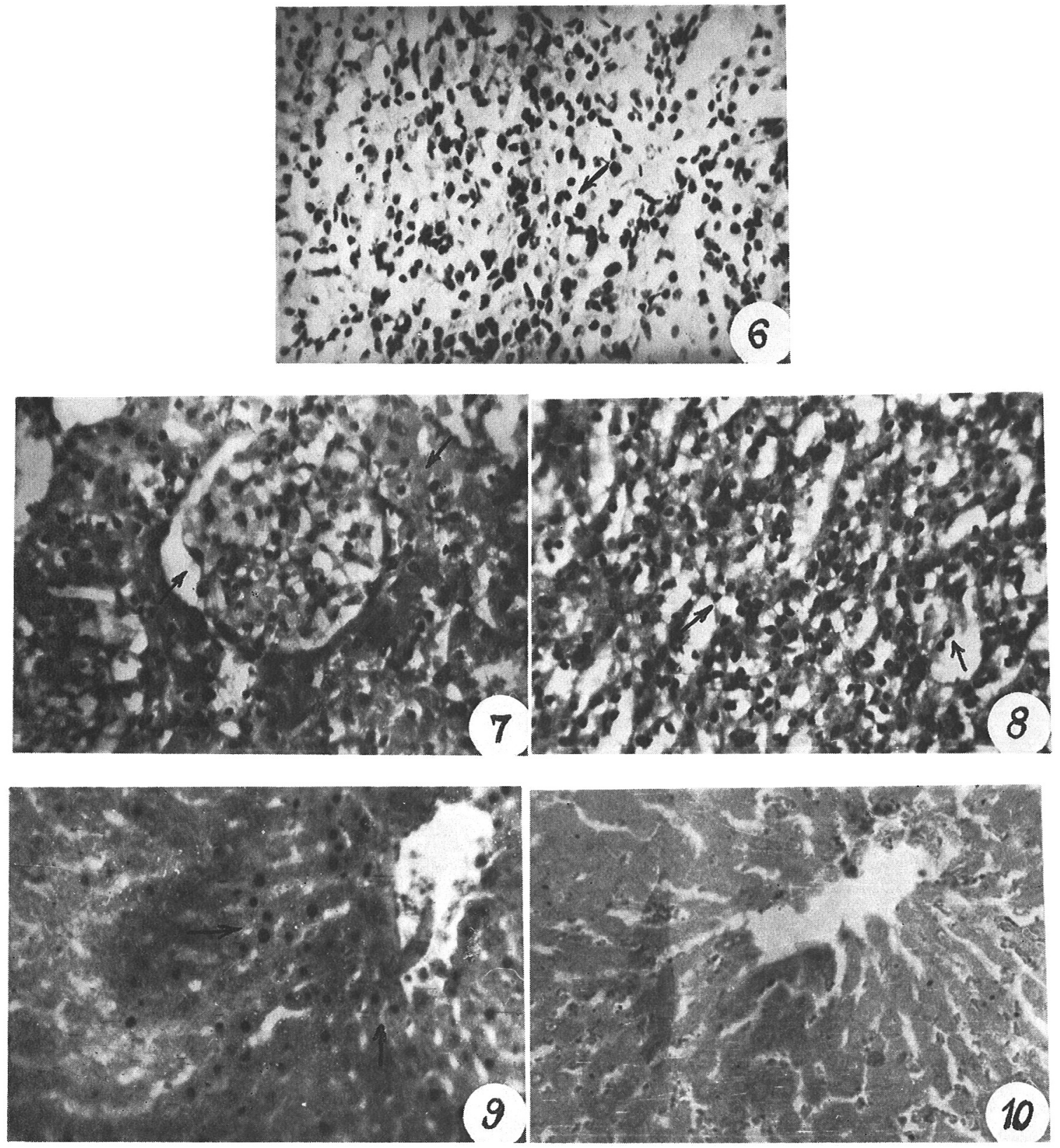

Fig. 6. Proliferation and clumping of the nuclei in the medulla of kidney has been caused by copper. $\times 240$.

Fig. 7. $\mathrm{Cu}+\mathrm{Mo}$ treated rats show no necrosis but glomerulo-nephritis was observed. $\times 240$.

Fig. 8. In medulla of the kidney after $\mathrm{Cu}+\mathrm{Mo}$ treatment, nuclear pycnosis was observed. $\times 240$.

Fig. 9. Retention of copper chiefly at the centrolobular region is exhibited by the liver of copper treated rats. $\times 240$.

Fig. 10. No reaction for copper was traced in the liver of rats fed on $\mathrm{Cu}+\mathrm{Mo} . \times 240$. 


\section{EFFECT OF DIETARY Mo AND $\mathrm{Cu}$ ON COPPER ACCUMULATION}
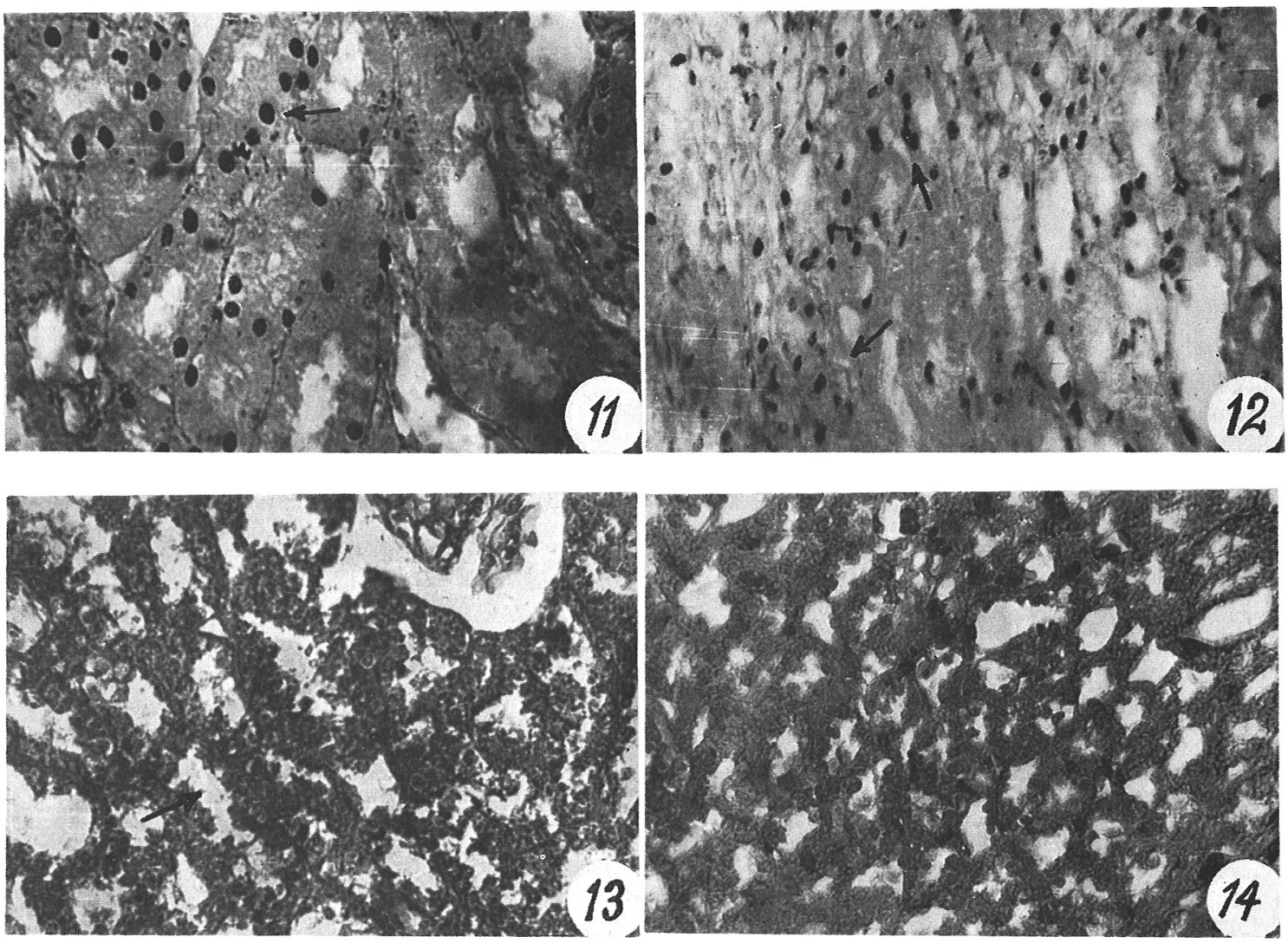

Fig. 11. Epithelial cells of distal tubules in kidney show accumulation of copper after copper treatment. $\times 320$.

Fig. 12. Few medullary cells also exhibit a positive reaction for copper. $\times 240$.

Fig. 13. Distal tubules of kidney also showed negative reaction for copper after feeding the rats on $\mathrm{Cu}+\mathrm{Mo} . \quad \times 240$.

Fig. 14. Medullary cells from the same section also showed the absence of copper. $\times 240$. 